\title{
V. S. Naipaul: The (Hi)Story of a pro-Western-very Eastern-storyteller
}

\section{Nabil Baazizi}

\section{(2) OpenEdition \\ Journals}

Electronic version

URL: https://journals.openedition.org/ces/5199

DOI: 10.4000/ces.5199

ISSN: 2534-6695

\section{Publisher}

SEPC (Société d'études des pays du Commonwealth)

\section{Printed version}

Date of publication: 1 April 2014

Number of pages: $51-60$

ISSN: 2270-0633

\section{Electronic reference}

Nabil Baazizi, "V. S. Naipaul: The (Hi)Story of a pro-Western-very Eastern-storyteller", Commonwealth Essays and Studies [Online], 36.2 | 2014, Online since 15 April 2021, connection on 19 July 2021. URL: http://journals.openedition.org/ces/5199 ; DOI: https://doi.org/10.4000/ces.5199

\section{(c) (i)}

Commonwealth Essays and Studies is licensed under a Licence Creative Commons Attribution - Pas d'Utilisation Commerciale - Pas de Modification 4.0 International. 


\section{S. Naipaul: The (Hi)Story of a pro-Western-very Eastern-storyteller}

This essay investigates the re-readings and rewritings of colonial canonical texts from the perspective of the colonized. Joseph Conrad's Heart of Darkness (1902) has been a particularly influential text for V. S. Naipaul. His novel $A$ Bend in the River (1979) can be seen as a rewriting of Conrad's novella. However, it also reflects his ambivalence towards the post-colonial struggle for decolonization as well as the persistent traditional Western conceptions of Africa and the Africans. This essay therefore explores the enigmatic in-betweenness and double-edgedness of Naipaul's work.

In the wake of decolonization, colonialist narratives have systematically been rewritten from indigenous perspectives. This phenomenon is referred to as "the Empire writing back to the centre"1 - a trend that asserted itself in late twentieth-century postcolonial criticism. The aim of such acts of writing back is to read colonialist texts in a Barthesian way, inside-out or à l'envers (Le Plaisir du Texte 44). Since, according to Barthes, "the reader indulges in crossing the given text with a fresh inscription," (Zabus, Tempests 3) reading becomes an act of rewriting. Turning the text inside-out and rereading it through the lens of a later code allows the postcolonial text to unlock the closures of its colonial precursor and change it from the inside. To re-enter a text with fresh eyes means the author indulges in a process of inversion. Extending Pierre Macherey's concept of the "thematic ancestor," I would call such a process an intentionally thematic misreading of previous texts. The post-colonial text, in this case, is unreadable without the echoes of its colonial counterpart, while the post-colonial writer, if he is to create his own new tradition, finds himself forced to understand and preserve, in order to cunningly cut the umbilical cord with his canonical "thematic ancestor."

Diana Brydon and Helen Tiffin use Macherey's concept to describe a reading process that highlights differences and similarities between the postcolonial text and its colonial thematic ancestor. When the thematic ancestor is transported to the present, it undergoes certain alterations. These transported ancestral structures "underwent transformations as they moved from the old world to the new ones" (90). These differences are what render the postcolonial text revolutionary since "ancestry need not imply mimicry or even continuity. The relation of the postcolonial text to its thematic ancestors is often parodic. [...] In the postcolonial context, parody often establishes a dialogue where first there was only monologue" (89).

Chinua Achebe's critique provides an entry point into these rewriting strategies. However, my endeavour is not an attempt to give full credence to Achebe's sweeping denunciation of Conrad and Naipaul. As I believe Conrad was an anti-imperialist writer,

1. "The Empire Writes Back to the Centre" is the title of an article by Salman Rushdie published in The London Times on July 3, 1982. The phrase is now widely used to describe the postcolonial rewriting of colonial canonical texts.

2. In his nigh-canonical A Theory of Literary Production (1966), Macherey argues that any creative work flourishes out of an "enabling model" (50) and that Robinson Crusoe is the "thematic ancestor" of the modern theme of a man being stranded on an island (240). In a similar way, I shall try to identify Joseph Conrad as the "thematic ancestor" - the "reservoir of symbols" (235) - of contemporary writings about Africa, especially through the study of Heart of Darkness as the enabling structure of V. S. Naipaul's $A$ Bend in the River. 
and that ambivalence is rooted in Naipaul's writings about Africa, my reading draws on the work of those "outside" the African condition (Michael Gorra and Helen Hayward) and the stance of "insiders" (Achebe). This critical position must allow for the reconciliation, however uneasy, of Achebe's denunciation in Gorra and Hayward's more integrative approach. Taking cognizance of their different critical perceptions can become a way to effectively highlight Naipaul's (mis)appropriation of Conrad.

Before examining Naipaul's rewriting strategies, it would be fruitful to locate Naipaul within the postcolonial tradition of rewriting. The Trinidadian novelist is, in fact, difficult to pigeonhole within this movement. Does Naipaul "write back" to, that is criticize, or does he rewrite, and in a way adopt and justify, imperial ideology? Since not all "rewriting" involves "writing back" in terms of anti-colonial critique (Innes 57), Naipaul's position is ambivalent.

To my mind, Naipaul himself represents the best example of what Bhabha calls "a subject of difference that is almost the same, but not quite" (122 emphasis in the original). Naipaul is a colonial mimic who looks to the West for artistic and cultural models, therefore creates a literature of self-hatred that attempts to, but does not entirely succeed in, duplicating imperialist strategies. On the one hand, it is true that he detects imitative tendencies in all the postcolonial societies he visits. On the other hand, Naipaul's selfhatred, voiced through his hatred of Third World societies, is implicitly built on an artificial line of separation between what he is today ("a British citizen") and what his distant past was (Indian/Trinidadian). This dividing line echoes colonialist - and, ironically enough, nationalist - discourses both of which have always worked to maintain a difference between the authentic British and the distorted go-between. In reality, Naipaul is neither simply "one of us" (nationalist Third World writers) nor "one of them" (his metropolitan Anglo-American readers), to use Jane Kramer's terms. Consequently, he experiences the in-betweenness of the mimic man. Naipaul's place-sensibility and his loyalties to the British Empire have certainly created a pro-Western-very Easternstoryteller who continues his cultural and literary encroachment on Western traditions.

\section{Conrad: The "Thematic Ancestor" of Naipaul}

In a 1979 interview, Naipaul said that he chose the title $A$ Bend in the River (1978) for "the uplift in it" ("Interview" 11). He tried, however, to conceal a most direct influence, the traditional image of Africa he inherited from his literary mentor Conrad. The novel's title and the general undertone, as well as the unnamed central African setting evoke the similarly unnamed Congo of Heart of Darkness (1902). Undoubtedly, Naipaul used Heart of Darkness and his own article "A New King for the Congo: Mobutu and the Nihilism of Africa" (1974) as source material for his novel A Bend in the River. Although there is no direct reference, a Heart-of-Darkness undertow runs throughout the novel. It is to be taken for granted that, as Coetzee has argued, Naipaul's Africa comes out of Heart of Darkness (10), while its author "had been everywhere before him" as if to guide him in the same direction and to offer him "a vision of the world's half-made societies" ("Conrad's Darkness" 208). Consequently, most discussions of Naipaul's novels and essays on Africa include an analysis of what Harold Bloom would call his "anxiety of influence" vis-à-vis Conrad. Conrad, Rob Nixon points out, "has provided Naipaul with his most direct point of entry into mainstream British literature" (88). 
The standard image of Africa in colonialist discourse tends to describe the Africans as childlike in their lack of discipline, and not different from Africa, which remains a bushy country untouched by history. Naipaul's depiction of Africa is merely a reflection of the long European tradition that painted a whole continent dark. The non-identification of the setting in this novel confirms this image. When Naipaul does not explicitly refer to the Congo, he undoubtedly intends to broaden his narrative to include the whole continent. In this way, the "vacuity" of Africa, and by extension the Third World, seems to be his only preoccupation. Moreover, the darkness/light dichotomy, which runs throughout the novel, shares affinities with that of Heart of Darkness. Indeed, Naipaul's pessimistic vision of Africa echoes that of Conrad, who ostensibly uses the light/ darkness dichotomy to contrast European civilization with African barbarism. The fact that Naipaul has also written a Congo Diary confirms his role as Conrad's successor. Both Conrad and Naipaul preceded their fictional narrative by a visit to the Congo, and they both recorded the details of their travels. If Achebe's Conrad is a "purveyor of comforting myths" (Achebe 3), Naipaul can be seen as "a new purveyor of the old comforting myths" (28).

Nowadays, it is practically taken for granted that the central contradiction in Heart of Darkness lies in the way it discredits imperialism while at the same time reproducing - in a way adopting - its attitudes. Heart of Darkness degrades the Africans only to represent the "outraged law" attributable to the colonizing Belgians. However, since Conrad "sometimes, as in Lord Jim and Heart of Darkness, [...] says less than he intends" ("Conrad's Darkness" 213), Naipaul sets himself the task of adapting Conrad's stylistic strategies. To prove this legitimacy, Naipaul resorts to Conrad's definition of fiction, which is "experience pushed a little (and only very little) beyond the actual facts of the case for the perfectly legitimate, I believe, purpose of bringing it home to the minds and bosoms of the reader" (“Conrad's Darkness" 214). Nonetheless, Naipaul's critique of Conrad's fiction also offers insight into his own strategy of rewriting. Conrad, he claims, "sticks too close to the facts, if he had meditated on those stories he might have turned them into case histories" (214). Naipaul's own account, rather than sticking "too close" to a historical account, advocates, as in A Bend in the River, "trampling" on the African past. "We have to learn to trample on the past [...] the past can only cause pain" (BR 163-4).

\section{A Bend in the River: A Heart of Darkness Rewrite}

Achebe's reading of Heart of Darkness suggests that the humiliation of the native Congolese is necessary, for they serve as the raw material upon which European supremacy is built. Marlow's "animalizing" of the natives and his distinction between the animal and the human echoes $A$ Bend in the River's conclusion associated with the colonisation of those incapable of representing themselves. In $A$ Bend in the River, "the lunatic or drunken old men in rags, ready to snarl like dogs, taking their food to dark corners, to eat out of the sight of others" (205) are like Conrad's African "creatures" who walk on "all-fours" to "lap out" of their hands if they want to drink from the river, nearly like animals:

Near the same tree two more bundles of acute angles sat with their legs drawn up. One, with his chin propped on his knees, stared at nothing, in an intolerable and appalling manner: his brother phantom rested its forehead, as if overcome with a great weariness; and all about others were scattered in every pose of contorted collapse, as in some picture 
of a massacre or a pestilence. While I stood horror-struck, one of these creatures rose to his hands and knees, and went off on all-fours towards the river to drink. He lapped out of his hand, then sat up in the sunlight, crossing his shins in front of him, and after a time let his woolly head fall on his breastbone. (Heart of Darkness 25$)^{3}$

The most striking point in the two aforementioned quotes is the way Salim - and decades before him his literary ancestor Marlow - degrades the natives. By doing so, Sa$\mathrm{lim}$, the contemporary narratological spokesman of an old Western colonial enterprise, revives the general assumption that conquering and dominating the "backward" peoples can only be achieved through acts of dehumanization and reification. In the case of Salim's observations, dehumanization takes the form of likening the villagers to dogs who need a European master. They are minimized to the extent that their physical shape is no longer that of human beings. This mode of thinking serves to justify any acts of cruelty or brutality committed by the conquerors against the peoples they colonized. The Africans are then used as convenient figures in a tableau painted by the European - an image of backwardness they are supposed to fit. Since "slave peoples are physically wretched, half men in everything except in their capacity to breed the next generation" (BR 85), Naipaul appears to take it upon himself to bring them back under European rule.

Raymond, the Big Man's "white historian," who is able to move from the victories of the Pax Romana to the promised Pax Kinshasa without missing a detail, is busy writing a selection of the Big Man's speeches which he entitles The Essential Thoughts. The implication is that it is a white man, a European, who dresses up the speeches of this African leader since the African, according to this Naipaulian myth, is incapable of translating his thoughts and writing them down as history. Yet, at no stage in the novel, are we made aware that Africa has a history. There is only a compilation of violent confrontations between the wild forest and the greedy European exploitation of Africa and the Africans.

Naipaul's focus on the importance of history may be attributed to his personal sense of uprootedness. His traumatic relation with history derives from his sense of missing a society and a cultural heritage. In both $A$ Bend in the River and "A New King for the Congo," he insists on the need for individuals and whole societies to make sense of the past in order to understand the present and prepare for the future. According to Naipaul, African history in this sense is easily forgotten or oversimplified. While perhaps in the colonial period, the school histories neglected Africa and taught only the achievements of the Europeans, and to some extent those of the Arabs, post-independence history fails to restore Africa to Africans and perpetuates, in turn, all that could glorify the colonial past. History as it is now taught jumps from the past of the ancestors to the present of the Congo Free State without recourse to the imperial history. It is therefore, according to Naipaul, mere nostalgia (BR 53-4).

Similarly, for the Indian community where Salim has grown up, the past was simply the past. Without any historical or chronological scale of reference, "neither [his] father nor grandfather could put days to their stories. Not because they had forgotten or were confused; the past was simply the past" (BR 12). Salim's Indo-African background makes him an outsider of sorts or, more precisely, an insider with a degree of detachment. Put another way, Salim is an outsider watching with the nervousness of the in-

3. All further references are to the 1994 edition, hereafter HD, listed in the Works Cited. 
sider who develops "the habit of looking, detaching myself from a familiar scene and trying to consider it as from a distance. It was from this habit of looking that the idea came to me that as a community we had fallen behind. And that was the beginning of my insecurity" (BR 17). The price he pays for this detachment, however, is, like Ralph Singh in The Mimic Men, a permanent sense of insecurity. Salim speaks about one tide of history that brought his people to Africa and another that shall wash them away. It echoes the opening of Heart of Darkness with Marlow and his fellow sailors waiting at sea-reach of the Thames for the tide to carry them away to the sea.

Though The Big Man's New Domain, patterned after President Mobutu's "presidential domain" at Nsele, may claim that Africa is supposedly being modernised, Naipaul reminds us that the bush is never far away. The bush always reclaims the land, creeping up over and over again. As he declares in "A New King For the Congo," "everyone feels the great bush at his back. And the bush remains the bush with its logical life" (215). The bush is always ready to reclaim the clearing. It was able to cover Arab towns and European settlements, and silences postcolonial African violence. As Salim argues, "I knew that the slave people were in revolt and were being butchered back into submission. But Africa was big. The bush muffled the sound of murder, and the muddy rivers and lakes washed the blood away" (BR 60).

Salim's way to understand the logic of the bush is through his customer Zabeth, a magician as well as a trader. The African name Zabeth echoes (mimics) the Western name Elizabeth. Maybe Naipaul distorts the name of this African magician to suggest the Africans' failure to mimic the West. She is neither European (trader) nor African (magician). Similarly, Salim's lack of any sense of protection obscures the connotations of his name. Salim is an Arab name meaning "safe." Maybe Naipaul, aware of this ambivalence, named his narrator Salim to suggest that in the "demoralizing" Africa no one is safe. Zabeth is like the other Africans who are ostensibly depicted as "creatures of the forest," ill at ease in the town. Zabeth, like Conrad's Africans, behaves "as though she came out each time from her hidden place to snatch from the present (or the future) some precious cargo to take back to her people" (BR 10). The implication is that she still lags far behind the flow of history.

At the end of his journey throughout Zaire Naipaul matches the Conradian archetypes of Africa. Alluding to "the heart of darkness" in his Congo Diary, Naipaul observes the life of the river as unchanging: "So repetitive the scenes, the dug-outs, the huts $[. .$.$] We who were visitors go on, but that life on the river also goes on, goes$ on now" (8). Here, he opposes the mobility of the narrative with the stability of rural Zaire, which is an area outside narrative progression and where "history has vanished" (CD 9). Naipaul has always seen himself as "the interpreter of a disordered and fast changing world" (Rowe-Evans 55), a world, in a sense, without the "prehistoric" Africa. Salim imagines "being transported to the hidden forest villages, to the protection and secrecy of the huts at night - everything outside shut out, kept beyond some magical protecting line" (BR 89). The surroundings remain almost entirely unknown. Again, Naipaul's imagery of village life echoes Conrad: "You felt the land taking you back to something that was familiar, something you had known at some time but had forgotten or ignored, but which was always there. You felt the land taking you back to what was there a hundred years ago, to what had been there always" (BR 9-10). This passage recalls Marlow's sense of "remote kinship" with the "wild" and "passionate uproar." 
It was unearthly, and the men were - No, they were not inhuman. Well, you know, that was the worst of it - this suspicion of their being inhuman. It would come slowly to one. They howled and leaped, and spun, and made horrid faces; but what thrilled you was just the thought of their humanity - like yours - the thought of your remote kinship with this wild and passionate uproar. Ugly. (HD 51)

According to Conrad, Kurtz's going native arises from his kinship with all that is primitive. The wilderness is not dead. It exerts a force which appeals to him "by the awakening of forgotten and brutal instincts, by the memory of gratified and monstrous passions" (HD 94-5). Conrad's Congo is pre-historic since "going up that river was like travelling back to the earliest beginnings of the world, when vegetation rioted on the earth and the big trees were kings" (HD 66). Africa is then like Patusan in Lord Jim, where "the flow of history has largely bypassed" (Lord Jim 213). If history for the West has reached its end, as Francis Fukuyama claimed, Africa still cannot find the start. Africa does not have - and cannot find - a history by itself. It will always need the West. Salim corroborates this idea when he argues that "all that I know of our history and the history of the Indian Ocean I have got from books written by Europeans. [...] Without Europeans, I feel, all our past would have been washed away, like the scuff-marks of fishermen on the beach outside our town" (BR 13).

When reading $A$ Bend in the River, we feel that Africa has remained unchanged since Conrad's visit. "People would be living in villages more or less as they had lived for centuries" (BR 296). Ancient beliefs discussed at length in Heart of Darkeness still survive in $A$ Bend in the River. "The bush was full of spirits; in the bush hovered all the protecting presences of man's ancestors" (BR 73). These spirits provide a kind of protection for the political system. The Big Man is said to have a stick inhabited by spirits, while the rebels believe that spirits protect them against bullets. In this sense, Naipaul conjures up a colonialist-inspired mockery of the Africans' faith at the bend in the river, since psychological humiliation and degradation were some of the principles of imperial ideology. In $A$ Bend in the River, Achebe would argue, the degradation of the natives transcends the physical to mock what is spiritual. It proves, in this sense, Naipaul's colonialist-patterned need for a complete subjugation of the conquered peoples.Issues of violence and disorder are introduced early on in $A$ Bend in the River. The first bloody rebellion occurs before the beginning of the novel's action, during the independence movement. When Salim travels inland towards the heart of the continent, he meets a great wave of "African violence," as if in answer to decades of imperial exploitation: "the big lawns and gardens had returned to bush; the streets had disappeared; vines and creepers had grown over broken, bleached walls of concrete or hollow clay brick" (BR 30). The destructive hysteria of the rebels is brought back at the end of the novel.

They are going to kill everybody who can read and write, everybody who ever put on a jacket and tie, everybody who put on a jacket de boy. They're going to kill all the masters and all the servants $[\ldots]$ They are going to kill and kill. They say it is the only way, to go back to beginning before it's too late. (BR 322)

Since these Africans are denied the refinement of civilization and drawn back to the natural habitat of the forest, they are no longer expected to behave as human beings, and technology serves only to enhance their violence. Thus, Nazruddin tells us, "the country was now too small for its tribal hatreds. [...] Africa going back to its old ways with modern tools, was going to be a difficult place for some time" (BR 235-6). In "A 
New King for the Congo," Naipaul refers to the Mulelist slogan: "start again from the beginning." This is mentioned to emphasize African nihilism, a wish to wipe out and undo. This again would seem to be evidence that Africa lacks a history, where the bush has always been self-sufficient. According to Asako Nakai, Naipaul's search for beginnings "derives from his anxiety for his writing to have authority, a solid basis for his rootless, colonial experience. [...] Just so, Naipaul's insatiable quest for a beginning or an origin as the locus of authority, ironically, reveals him as being a colonial, without a past, without ancestors" (13).

The quest for origins is also problematized through references to antiquity. Miscerique probat populos et foedera jungi, meaning "he approves of the mingling of the peoples and their bonds of union" (BR 29) are the words that remain of a monument erected by the colonial authorities to commemorate the steamer service connecting the town to the capital. The inscription is a misquotation of Virgil (Coovadia n.p.). In The Aeneid, we read that Venus, who disapproves of the marriage between Dido and Aeneas, declares to Juno that she is uncertain "whether Jupiter [...] approves the blending of peoples and the league of union": Miscerive probet populos, aut foedera jungi (402). In A Bend in the River, the owners of the steamship company changed the line into an assertion that gods intervene, declaring their approval of the relations between the Africans and the Europeans. This deliberate misquotation staggered Salim:

Twisting two-thousand-year-old words to celebrate sixty years of the steamer service from the capital! Rome was Rome. What was this place? To carve the words on a monument beside this African river was surely to invite the destruction of the town. Wasn't there some little anxiety, as in the original line from the poem? (BR 71)

This is an Africa that travels back to the early beginnings as it moves forward, displacing Salim between a never-ending history and never-beginning future. In Salim's words, "to be among the ruins was to have your timesense unsettled. You felt like a ghost, not from the past but from the future [...] You were in a place where the future had come and gone" (BR 30). We can find the same misquotation in a badge that commemorates the centenary of the conquest of Trinidad by the British. As a British colony, Trinidad was granted a shield portraying a British ship arriving in harbour above a ribbon with the same misquotation: "Miscerique probat populos et fecdera jungi." At this point, it might be judicious to point out, as Coovadia and Feder do, that misquotation is practised both by Europeans and postcolonial subjects - for different reasons, naturally.

The savage murder of Father Huismans, who got his head spiked, and the chaos in which Africa is now falling would mean that gods do not approve of the relations between the Europeans and the Africans at this bend in the river. Lillian Feder suggests as much:

[Father Huismans] reacts differently. The paired Latin quotations define his conception of his role in Africa. He takes delight in every new revelation of the spiritual life of the country and uses the altered quotation from the Aeneid to place himself within "an immense flow of history," as a European to whom the Latin words apply. (229)

Conversely, the two most important Africans to whom Naipaul gives a voice in the novel, Metty and Ferdinand, are denied pure Africanness, and, therefore, are not representative of the Africans. Mustapha (or Metty, whose name is derived from the French métis, someone of mixed race), has "the blood of the Gujarat in his veins" (BR 16), while Zabeth's son, Ferdinand, is "of mixed tribal heritage, and in this part of the 
country he was a stranger. He had no group that was really his own, and he had no one to model himself on" (BR 53). In order to overcome his identity problems, Ferdinand resorts to adopting roles. In a mimic-man mannerism, he first tries on the character of "the new African on the way up," and wearing the lycée blazer with the Semper Aliquid Novi motto which helps him imagine himself as a European teacher. Later, when some boys from a warrior tribe come to the lycée, Ferdinand decides to try out the role of the indolent forest warrior (BR 60). In Salim's view, Ferdinand is barely out of the bush, but he has been to school. He has changed his African clothes for the Western lycée blazer. Here Naipaul's ambivalence surfaces. The implication is that the African fails to adhere to an African ethos, while he ambivalently misappropriates the model of his colonizer.

Conrad's reference to the Roman Empire serves as a reminder that England was once one of the dark places of the earth. There is a Conradian paradox in Naipaul's representation of European civilization: "If it was Europe that gave us on the coast some idea of our history, it was Europe, I feel, that also introduced us to the lie" (BR 19). Michael Gorra judiciously points out that Naipaul's ambivalence is due to his inability to oppose bush and civilization: "the opposition between civilization and bush is never so absolute as it seems" (104). Naipaul's enigmatic reference in Congo Diary to "Rome and Belgium" (8) implies that he believes there is some basis for a comparison between the two empires. I would argue that Naipaul is again ambivalent. Ruin serves as a reproach to departed colonialists, and simultaneously as a criticism of European civilization. He writes about the "perishability of the machine civilization. How quickly things fail," (CD 41) noting that "the Empire of things. Exporters of what civilization? The perishable" (CD 42). He compares it with "earlier imperialism: the source of new ideas" (CD 15). Naipaul's A Congo Diary, in this vein, is a more explicitly severe critique of nineteenth-century imperialism and its consequences than $A$ Bend in the River, where modernity is seen as superficial and merely imported European notions. The Domain as well as Mahesh's Bigburger enterprise do not stem from a pure African heritage. They miss African Africa. In this regard, Helen Hayward argues,

$A$ Bend in the River is deeply ambivalent in its account of European society. Europe represents a lost ideal of peace and order, but has also given rise to junk civilization. The novel suggests that its deeds fall short of its ideals; Europe itself has succumbed to the pull of disorder, and it exports naïve ideologues to the rest of the world [...] The novel employs traditional images of Africa to give symbolic form to a confusion and disruption not confined to Africa. (176)

Sometimes Europe embodies order, and at other times it is portrayed as a purveyor of a culture of junk to its colonies. The Big Man seeks Europe for modernity while implying that modernity is not worth having. The natives squat in the ruins of the departed civilization. Instead of trying to master technologies left by the departed Europeans, they are filled with rage against it. "The rage of the rebels was like a rage against metal, machinery, wires, everything that was not of the forest and Africa" (BR 91). This is Naipaul's nostalgia towards the ruins which recall the immensity and grandeur of the Belgian Empire while simultaneously suggesting that Europe is the source of junk.

Naipaul, like his narrator-protagonist in The Mimic Men, Ralph Singh, feels "shipwrecked" in Trinidad. Seeking a higher order, he is again shipwrecked in a "greater disorder, the final emptiness: London and the home countries" (7). Indeed, by looking briefly at their biographies, one comes to realize how profoundly Conrad and Naipaul were 
influenced by their lack of a sense of belonging. Being Indian by ancestry, Trinidadian by birth, and British by intellectual training, Naipaul - like Conrad, the Polish, the Ukrainian, and the British - lives in constant exile. "Even in his homeland, Trinidad," Emanuela Cristina Dascalu argues, "Naipaul is an exile, an exile from India. In England, he is an exile from Trinidad. In India, he is not 'at home' because it is a country he has never known" (93). The Trinidadians, and to a lesser degree the Poles, experienced to the full the absence of a common identity that characterizes all societies. Among the Trinidadians anti-imperialistic drives were impossible; on the contrary, it was rather their "Britishness," their sense of being part of the British Empire which gave them their identity. In this heterogeneous society, Naipaul was a member of a minority race and religion; like Conrad, Naipaul was doubly marginalized, first within the Trinidadian society and later on within the metropolitan centre.

Through their sense of alienation, displacement, and perpetual exile, both Conrad and Naipaul have established a tradition unique to the late nineteenth and the twentieth centuries. The fact that they spent their lives as international wanderers, "shipwrecked" in different cultures, allows the identification of a line of descent that links their works. Like Conrad who worked to reconcile his Polish past with his British present through art, Naipaul found himself straddled between cultures and therefore obliged to take on the only identity open to him: that of a writer. Most of Naipaul's novels adopt the idea of a return to one's origins, but finally we are led to understand that he seeks a balance between two opposing forces within himself, the call of origins and the urge to continue as an exile. Thus Naipaul occupies an in-between space, while his novels continue his constant quest for an identity.

However, while Conrad recognized the wrongs of imperialism at a period when most European writers laid emphasis on conquering the still "backward societies," Naipaul has silenced his "thematic ancestor" to give way to his own neo-colonialist ideology. Graham Huggan argues that

By emptying his precursor's work of its moral afflatus, Naipaul relocates it in a context which instead of distinguishing between right and wrong, or exploring the contradictions involved in such distinctions, stresses grassroots survival and the acknowledgment of inevitable insecurity. (10)

Naipaul misappropriates the double-edgedness which characterized Conrad's way of conceiving of the relations between the Europeans and the natives. In Naipaul's work, Conrad becomes a disabled "thematic ancestor" that has been radically altered during the rewriting. In his attempt to exhume Conrad, Naipaul recasts and redefines the Conradian archetype.

Nabil BAAZIZI

University Sorbonne Nouvelle - Paris 3

\section{Works Cited}

AcheBe, Chinua. Hopes and Impediments. New York: Doubleday, 1989.

Ashcroft, Bill, Helen Tiffin, and Gareth Griffiths. The Empire Writes Back: Theory and Practice in PostColonial Literature. London: Routledge, 1989.

Brydon, Diana, and Helen TifFin. Decolonising Fictions. Sydney: Dangaroo, 1993. 
BARTHes, Roland. Le Plaisir du Texte. Paris: Seuil, 1973.

BLOOM, Harold. The Anxiety of Infuence. Oxford: Oxford UP, 1973.

BнавнA, Homi. The Location of Culture. London: Routledge, 1994.

Coetzee, J. M. “The Razor's Edge.” The New York Review of Books 48.17 (2001): 8-10.

ConRAD, Joseph. Lord Jim. 1899. New York: Norton, 1996.

—. Heart of Darkness. 1902. London: Penguin, 1994.

Coovadia, Imraan. "Authority and Misquotation in V. S. Naipaul's A Bend in the River." Postcolonial Text 4.1 (2008): http://postcolonial.org/index.php/pct/article/view/746/527 (last accessed 19 March 2014).

Dascalu, Emanuela Cristina. Imaginary Homelands of Writers in Exile: Salman Rusbdie, Bharati Mukherjee, and V. S. Naipaul. New York: Cambria P, 2007.

FeDER, Lillian. Naipual's Truth. The Making of a Writer. Maryland: Rowman \& Littlefield, 2001.

GorRA, Michael. After Empire: Scott, Naipaul, Rushdie. Chicago: Chicago UP, 1997.

HaYward, Helen. The Enigma of V. S. Naipaul: Sources and Contexts. Houndmills: Macmillan, 2002.

HugGan, Graham. "Anxieties of Influence: Conrad in the Caribbean." Commonwealth Essays and Studies 11.1 (1988): 1-12.

InNes, C. L. "The Politics of Rewriting." A Concise Companion to Postcolonial Literature. Ed. Shirley Chew and David Richards. Chichester: Wiley-Blackwell, 2010. 56-77.

Kramer, Jane. "From the Third World." The New York Times Book Review, April 13, 1980: 1, 30-2.

Lamming, George. The Pleasures of Exile. London: Michael Joseph, 1960.

Macherey, Pierre. A Theory of Literary Production. Trans. Geoffrey Wall. 1966. London: Routledge, 1978.

Mohan, Champa Rao. Postcolonial Situation in the Novels of V. S. Naipaul. New Delhi: Atlantic, 2004.

Naipaul, V. S. The Mimic Men. London: Picador, 1967.

—. "Conrad's Darkness." The Return of Eva Peron, with the Killings in Trinidad. Harmondsworth: Penguin Books, 1974. 197-218.

- "A New King for the Congo: Mobutu and the Nihilism of Africa." The Return of Eva Peron, with the Killings in Trinidad. Harmondsworth: Penguin Books, 1974. 165-96.

—. Congo Diary and Other Uncollected Pieces. Ed. Zdzislaw Njder. New York: Doubleday, 1978.

—. Interviewed by David Pryce-Jones. Radio Times, 24-30 March 1979.

-. A Bend in the River. London: Picador, 1979.

NAKAI, Asako. "Journey to the Heart of Darkness: Naipaul's 'Conradian Atavism' Reconsidered." The Conradian 23.2 (Autumn 1998): 1-16.

Nixon, Rob. London Calling: V. S. Naipaul, Postcolonial Mandarin. Oxford: Oxford UP, 1992.

Nkosi, Lewis, "Conversation with Chinua Achebe." African Writers Talking. Ed. Dennis Duerden and Cosmo Pieterse. London: Heinemann, 1978.

RushdiE, Salman. “The Empire Writes Back With a Vengeance.” The London Times July 3, 1982: 8.

SAID, Edward. Culture and Imperialism. New York: Vintage, 1993.

VIRGIL. Eclogues, Georgics and Aeneid. Trans. Rushton Fairclough. Cambridge, MA: Harvard UP, 1935.

Zabus, Chantal. "Wreaders. On the Practice of 'Rewriting' at the End of the Twentieth Century." Alizés 20 (2001): 191-205.

—. Tempests after Shakespeare. New York: Palgrave, 2002. 